\title{
Social Class and Social Cohesion: A Content Validity Analysis Using a Nonrecursive Structural Equation Model
}

\author{
CARLES MUNTANER, ${ }^{a, b, c}$ GARY OATES, ${ }^{c, d}$ AND JOHN LYNCH ${ }^{e}$ \\ ${ }^{b}$ Department of Psychiatric and Community Health, \\ University of Maryland-Baltimore, Baltimore, Maryland 21201-1579, USA \\ ${ }^{c}$ National Institute of Mental Health, Bethesda, Maryland 20892, USA \\ ${ }^{d}$ Department of Sociology, University of Connecticut, \\ Storrs, Connecticut 06269-2068, USA \\ ${ }^{e}$ Department of Epidemiology, University of Michigan, \\ Ann Arbor, Michigan 48109-2029, USA
}

The psychosocial construct of "social cohesion," understood as social behaviors indicating trust, reciprocity, and concern for the well-being of the members of one's community, is the key determinant of health in the "income inequality and social cohesion model" model (Ref. 1, p. 211). Social cohesion is defined as participation in public affairs, civic responsibility or involvement in public life. Social cohesion can be measured with indicators of voting participation, newspaper readership, or number of cultural voluntary associations (Ref. 1, p. 119-120). Here we define social cohesion as the amount of individual participation in social groups in the community. Indicators of membership in civil organizations, a measure of social cohesion used in the "income inequality and social cohesion" research program, ${ }^{1}$ would be appropriate according to that definition. But in order for a psychometric measure to have content validity, it must include a representative sample of indicators of the construct it is supposed to measure. Current measures of social cohesion downplay or do not include forms of participation in social groups that are characteristic of working class communities such as union membership. ${ }^{2}$ Furthermore, these working class forms of cohesion can affect the health of communities through labor and political action (e.g., research on collective control ${ }^{3}$ ). However, the "income inequality and social cohesion" model does not contemplate the relation between class and social cohesion. In political sociology, research within the resource mobilization framework has revealed that members of the middle class have more time and resources to devote to civic participation than members of the working class. ${ }^{4}$ Therefore we expect that the forms of civic social activism tapped by current indicators 1 will be associated with middle class location and negatively associated with working class location. Next, because group participation antecedes collective political participation (e.g., voting, strikes ${ }^{4}$ ), we hypothesize that Wilkinson's form of organization membership will mediate the association between middle class and political

\footnotetext{
${ }^{a}$ Address for correspondence: Carles Muntaner, Ph.D., P.O. Box 1579, University of Maryland School of Nursing, 655 West Lombard Street, Baltimore, MD 21201-1579, USA.

e-mail: cmontane@wvu.edu
} 
participation whereas union membership will be the mediator of political participation for working class locations. In testing these hypotheses, we take into account the role of potential confounders such as expected efficacy of individual political action, income, and education.

The study utilizes data from the American $(n=1719)$ and British $(n=1458)$ portions of the Political Action I survey, and subsample $(n=523)$ of the American portion of the Political Action II survey. ${ }^{5}$ This subsample comprises of respondents to the Political Action I survey who were reinterviewed seven years later as part of the Political Action II project. The American portion of the Political Action I survey was conducted between June and September of 1974, and the American Portion of the Political Action II survey was conducted between May and September of 1981. Both surveys are based on multistage area probability samples of households. A structural equation model (SEM) with latent variables was used to determine the relative mediating roles of civic organization and union membership and their relation to social class. These models combine structural equation and factor modeling and directly adjust for the fact that latent variables are imprecisely measured. ${ }^{6}$ The exogenous variables are the dichotomous social class indicator (working class location versus nonworking class location) and the two control variables, income and education. The explanatory variables are social cohesion (membership in civic organizations and union membership), individual perceptions of political efficacy and the two ultimate dependent variables are conventional participation and legal protesting. Four of the variables included in this model-organization membership, political efficacy, conventional participation, and legal protesting - are latent variables. Loadings and descriptions for these indicators are listed in TABLE 1. The model, presented in TABLE 2, is designed to remove the effects of political efficacy and organization or union membership on participation of any reciprocal relationship between the two variables. It utilizes panel data from the sample of Americans who were interviewed in 1974 and again in 1981. Identification is obtained by using the time 1 measures of organization membership, union membership, and political efficacy as instruments for their time 2 counterparts, and by excluding cross-lagged effects from the model. The RMSEA was used to assess the similarity between the observed and the estimated variance-covariance matrices.

Findings from the reciprocal effects models are both consistent with the notion that organization membership and union membership are associated with "nonworking class" (i.e., capitalist, manager, and professional locations) and working class locations, respectively, and that both forms of social cohesion are mediators of the social class-political participation relationship (see TABLE 2). Organization membership is a significant function of social class, rendered less likely by working class location. The likelihood of union membership is enhanced by working class position. In spite of the good fit of the model, a relative low sample in the analysis of reciprocal effects cautions against strong inferences and recommends replication of these results with larger samples.

These results are consistent with the conclusion that measures of social cohesion in the "income inequality and social cohesion" research program lack content validity, because they exclude forms of social cohesion emerging from working class communities. This might result in a characterization of these communities as not socially cohesive and attribute their population health experience to this alleged col- 
TABLE 1. Factor loadings for each indicator in the model's four latent variables: conventional participation, legal protest, political efficacy, and organization membership ${ }^{a}$

\begin{tabular}{|c|c|c|c|}
\hline \multirow[b]{2}{*}{ Latent variable } & \multicolumn{2}{|c|}{ Reciprocal effects model } & \multirow[b]{2}{*}{ Description } \\
\hline & Time 1 & Time 2 & \\
\hline \multicolumn{4}{|c|}{ Conventional participation $b$} \\
\hline Meeting & - & 0.72 & [How often do you] "attend a political meeting or rally?" \\
\hline Official & - & 0.71 & “...contact public officials or politicians?" \\
\hline Campaign & - & 0.69 & "...spend time working for a political party or candidate?" \\
\hline Work & - & 0.64 & $\begin{array}{l}\text { "...work with other people in this community to try to } \\
\text { solve some local problem?" }\end{array}$ \\
\hline Discuss & - & 0.55 & “...discuss politics with people?” \\
\hline Convince & - & 0.41 & "...try to convince friends to vote the same as you?" \\
\hline Voted & - & 0.36 & "Did you vote in the [last general] election?" \\
\hline \multicolumn{4}{|l|}{ Legal protest ${ }^{c}$} \\
\hline Boycott & - & 0.51 & "Joining in boycotts." \\
\hline Demo & - & 0.54 & "Attending lawful demonstrations." \\
\hline Petition & - & 0.48 & "Signing a petition." \\
\hline \multicolumn{4}{|l|}{ Political efficacy $^{d}$} \\
\hline Don't care & 0.76 & 0.82 & $\begin{array}{l}\text { "I don't think public officials care much about what people } \\
\text { like me think." }\end{array}$ \\
\hline Notopin & 0.81 & 0.75 & $\begin{array}{l}\text { "Parties are only interested in people's votes, but not their } \\
\text { opinions." }\end{array}$ \\
\hline Losetie & 0.77 & 0.64 & $\begin{array}{l}\text { "Generally speaking, people we elect to congress lose } \\
\text { touch with the people pretty quickly." }\end{array}$ \\
\hline Nosay & 0.58 & 0.61 & "People like me have no say in what the government does." \\
\hline \multicolumn{4}{|c|}{ Organization membership ${ }^{e}$} \\
\hline Polorg & 0.42 & 0.43 & Political party \\
\hline Polorg2 & 0.22 & 0.26 & Other political organizations \\
\hline Proforg & 0.50 & 0.65 & Professional associations \\
\hline Intgporg & 0.30 & 0.29 & Special interest groups or hobbies \\
\hline Civicorg & 0.35 & 0.42 & Civic groups \\
\hline Raceorg & 0.12 & 0.16 & Racial or ethnic organizations \\
\hline
\end{tabular}

${ }^{a} p<0.01$ or $p<0.05$ for each loading. Control variables: $Z$ of family income-standardized (gross yearly) family income in dollars/pounds. $Z$ of family education-respondent's education in years.

${ }^{b}$ The first six indicators are accompanied by the following response categories: 4 , often; 3 , sometimes; 2 , seldom; 1 , never. The seventh (voted) is a dichotomy $(1$, yes) $(0$, no) .

${ }^{c}$ Accompanying response categories are the following: 4 , often; 3 , sometimes; 2 , seldom; 1 , never

${ }^{d}$ Accompanying response categories are the following: 1 , strongly agree; 2 , agree; 3 , disagree; 4 , strongly disagree.

${ }^{e}$ For each item, membership is coded 1 and nonmembership 0. Class was assigned according to response: (1) working class-employees who fall within none of the four middle-upper class occupation categories (see 0 response occupation categories); (0) middle and upper class-a combination of the following occupational categories:

- capitalists-self-employed and supervising at least one person;

- self-employed-self-employed and supervising no one;

- supervisors-employed individuals who supervise others;

- professional/managerial — nonsupervisory employed individuals who hold/held jobs classified as such by the ILO.

NOTE: Classifications are based on respondents' current or last job. Respondents who had never held a paid job were excluded from the analysis. 
TABLE 2. Estimates for reciprocal effects model: standardized coefficients reported ${ }^{a, b}$

\begin{tabular}{lccccccccc}
\hline & $\begin{array}{c}\text { Political } \\
\text { efficacy }\end{array}$ & & \multicolumn{2}{c}{$\begin{array}{c}\text { Organization } \\
\text { membership }\end{array}$} & $\begin{array}{c}\text { Union } \\
\text { membership }\end{array}$ & $\begin{array}{c}\text { Conventional } \\
\text { participation }\end{array}$ & $\begin{array}{c}\text { Legal } \\
\text { protest }\end{array}$ \\
& $(\mathrm{T} 1)$ & $(\mathrm{T} 2)$ & $(\mathrm{T} 1)$ & $(\mathrm{T} 2)$ & $(\mathrm{T} 1)$ & $(\mathrm{T} 2)$ & $(\mathrm{T} 2)$ & $(\mathrm{T} 2)$ \\
\hline $\begin{array}{l}\text { Working } \\
\text { class (T1) }\end{array}$ & 0.05 & - & $-0.17^{c}$ & - & $0.23^{c}$ & - & 0.09 & 0.02 \\
$\begin{array}{l}\text { Political } \\
\text { efficacy (T1) }\end{array}$ & - & $0.57^{c}$ & - & - & - & - & - & - \\
$\begin{array}{l}\text { Political } \\
\text { efficacy (T2) }\end{array}$ & - & - & - & 0.03 & - & 0.05 & 0.06 & -0.03 \\
$\begin{array}{l}\text { Organization } \\
\text { membership (T1) }\end{array}$ & - & - & - & $0.84^{a, c}$ & - & - & - & - \\
$\begin{array}{l}\text { Organization } \\
\text { membership (T2) }\end{array}$ & - & $0.16^{c}$ & - & - & - & - & $0.55^{c}$ & $0.24^{c}$ \\
$\begin{array}{l}\text { Union } \\
\text { membership (T2) }\end{array}$ & - & - & - & - & - & $0.71^{c}$ & - & - \\
$\begin{array}{l}\text { Union } \\
\text { membership (T2) }\end{array}$ & - & -0.01 & - & - & - & - & 0.04 & $0.34^{c}$ \\
$\begin{array}{l}Z \text { of family } \\
\text { income (T1) }\end{array}$ & 0.10 & - & $0.17^{d}$ & - & $0.14^{c}$ & - & $0.10^{e}$ & $0.13^{e}$ \\
Education (T1) & $0.31^{c}$ & - & $0.67^{c}$ & - & -0.07 & - & 0.06 & $0.35^{c}$ \\
\hline
\end{tabular}

${ }^{a}$ The errors between organization membership at time 1 and time 2 were allowed to correlate. ${ }^{b}$ RMSEA $=0.035 ; \chi^{2}=870.78 ; d f=626$.

${ }^{c} p<0.01$.

${ }^{d} p<0.05$.

${ }^{e} p<0.10$.

lective liability. The unintended consequence of such characterization could be to fuel punitive or moralistic policies. ${ }^{2}$

\section{ACKNOWLEDGMENTS}

This work was supported by the funds from NIMH and CDC, project \# Z01 MH02610-04, Z01 MH02610-05, U48/CCU310821 (Dr. Muntaner). The contents are solely the views of the authors and do not necessarily represent the official views of the aforementioned funding agencies.

\section{REFERENCES}

1. Wilkinson, R.G. 1996. Unhealthy Societies: The Afflictions of Inequality. Routledge, London.

2. Fox Piven, F. \& R.A. Cloward. 1999. The Breaking of the American Social Compact. Vintage Books, New York. 
3. Johnson, J.V. \& G. Johansson. 1991. The Psychosocial Work Environment: Work Organization, Democratization and Health. Baywood, New York.

4. Jenkins, C.J. \& B. KLandermans. 1995. The Politics of Social Protest: Comparative Perspectives on States and Social Movements. University of Minnesota Press, Minneapolis.

5. JoReskog, K.G. \& A.-M. Aish. 1990. A panel model for political efficacy and responsivenesss: an application of LISREL 7 with weighted least squares. Qual. Quant. 24: 405-426.

6. Joreskog, K.G. \& D. Sorbom. 1993. Lisrel 8 User's Reference Guide. Scientific Software International, Chicago. 